\title{
PENGEMBANGAN APLIKASI INFORMASI RUTE ANGKUTAN KOTA BANDAR LAMPUNG BERBASIS ANDROID
}

\author{
${ }^{1}$ Rico Andrian, ${ }^{2}$ Febi Eka Febriansyah, ${ }^{3}$ Basir Efendi, \\ 1,2,3 Jurusan Ilmu Komputer FMIPA Unila \\ ${ }^{1}$ rico.andrian@fmipa.unila.ac.id, \\ ${ }^{2}$ febi.febriansyah@fmipa.unila.com, ${ }^{3}$ basir.efendi@gmail.com
}

\begin{abstract}
This research is done to design and build Information Application of Bandar Lampung City's Public Transportation with Android. This application can be used as a media to know about Bandar Lampung's Public Transportation and the routes which is used by Bandar Lampung City's public transportation, and the benefit of this application is to help citizen who does not know Bandar Lampung City to know about the routes of Bandar Lampung City's public transportation. Application of Bandar Lampung City's Public Transportation uses java programming language. Development of the application uses Unified Process (UP) method and is designed with Unified Modeling Language (UML). The result produced in the test using Equivalence Paritioning shows that system's management of rules are able to run well and the system can provide information well. Base on testing data, this application is categorized as User Friendly with the average of $83,67 \%$ (Very Good).
\end{abstract}

Keyword: Android, Angkot, Bandar Lampung City’s Public Transportation

\section{Pendahuluan}

Angkutan umum adalah salah satu jenis sarana transportasi yang paling banyak digunakan oleh masyarakat sehari-hari, karena biaya yang relatif murah dan terjangkau oleh sebagian besar kalangan masyarakat. Kota Bandar Lampung adalah salah satu dari kota terbesar ketiga di pulau Sumatera yang mempunyai angkutan umum dengan populasi yang padat. Permasalahan yang perlu diperhatikan dalam transportasi angkutan umum di kota Bandar Lampung itu adalah kebingungan masyarakat dalam mencari jalur yang dilalui angkutan umum karena kurangnya informasi mengenai rute angkutan umum yang begitu banyak di kota Bandar Lampung, khususnya bagi masyarakat yang berkunjung ke kota Bandar Lampung. Pentingnya perencanaan rute dalam transportasi maka kebutuhan akan informasi mengenai rute angkutan umum di kota Bandar Lampung. [1]

Penelitian sebelumnya yaitu layanan berbasis Android yang diteliti oleh Singhal. Layanan ini, memiliki keuntungan bagi penggunanya, salah satunya yaitu untuk memperoleh informasi tentang lokasi pengguna saat ini. Layanan lokasi dapat diimplementasikan ponsel berbasis Android dengan memberi saran kepada pengguna kondisi lalu lintas saat sini, memberikan informasi rute, dan membantu menemukan hotel di sekitar lokasi. Metode yang digunakan dalam penelitian ini menggunakan LBS (location based services), untuk mengolah data lokasi di server dan meneruskan respon yang dihasilkan kepada pengguna, dan menemukan data lokasi untuk aplikasi berbasis perangkat mobile yang dapat menggunakan secara langsung. Hasil pada penelitian yang dilakukan, pengguna untuk mencari lokasi suatu tempat, menggunakan google Places API untuk mencari tempat berserta rincian mengenai lokasi.[2]

Penelitian sebelumnya yaitu sistem real-time trip-planner Transportasi Umum yang diteliti oleh Alves, memiliki kemampuan dalam mengetahui tentang rute terbaik. Proses data mining untuk mengalisis informasi perjalanan dan kecepatan, bertujuan untuk simulasi perjalanan. Metode yang 
digunakan adalah algoritma Dijkstra. Algoritma Dijkstra adalah pencarian grafik memecahkan satu sumber masalah jalur terpendek. Hasilnya dapat mengetahui rute terbaik dengan tingkat akurasi tinggi, sangat bagi pengguna angkutan umum.[3]

Penlitian sebelumnya dapat berguna untuk Angkutan umum di Bandar Lampung. Angkutan umum merupakan transportasi yang banyak diminati penumpang karena tarifnya yang ekonomis dibandingkan transportasi lainnya. Masyarakat yang belum mengenal daerah Kota Bandar Lampung atau pendatang dari luar kota mengalami kesulitan dalam memilih angkutan umum Bandar Lampung.

Manfaat dari penelitian ini adalah mempermudah masyarakat yang belum mengenal kota Bandar Lampung, untuk mengetahui rute angkutan kota Bandar Lampung.

\section{Metodologi}

Algoritma dijkstra ini merupakan salah satu bentuk algoritma greedy. Algoritma ini termasuk algoritma pencarian graph yang digunakan untuk menyelesaikan masalah lintasan terpendek dengan satu sumber pada sebuah graph yang tidak memiliki cost sisi negatif, dan menghasilkan sebuah pohon lintasan terpendek. Algoritma ini sering digunakan pada routing.

\section{a. Test case pada graph trayek angkutan kota}

Berikut ini adalah graph angkutan kota rajabasa-tanjung karang.

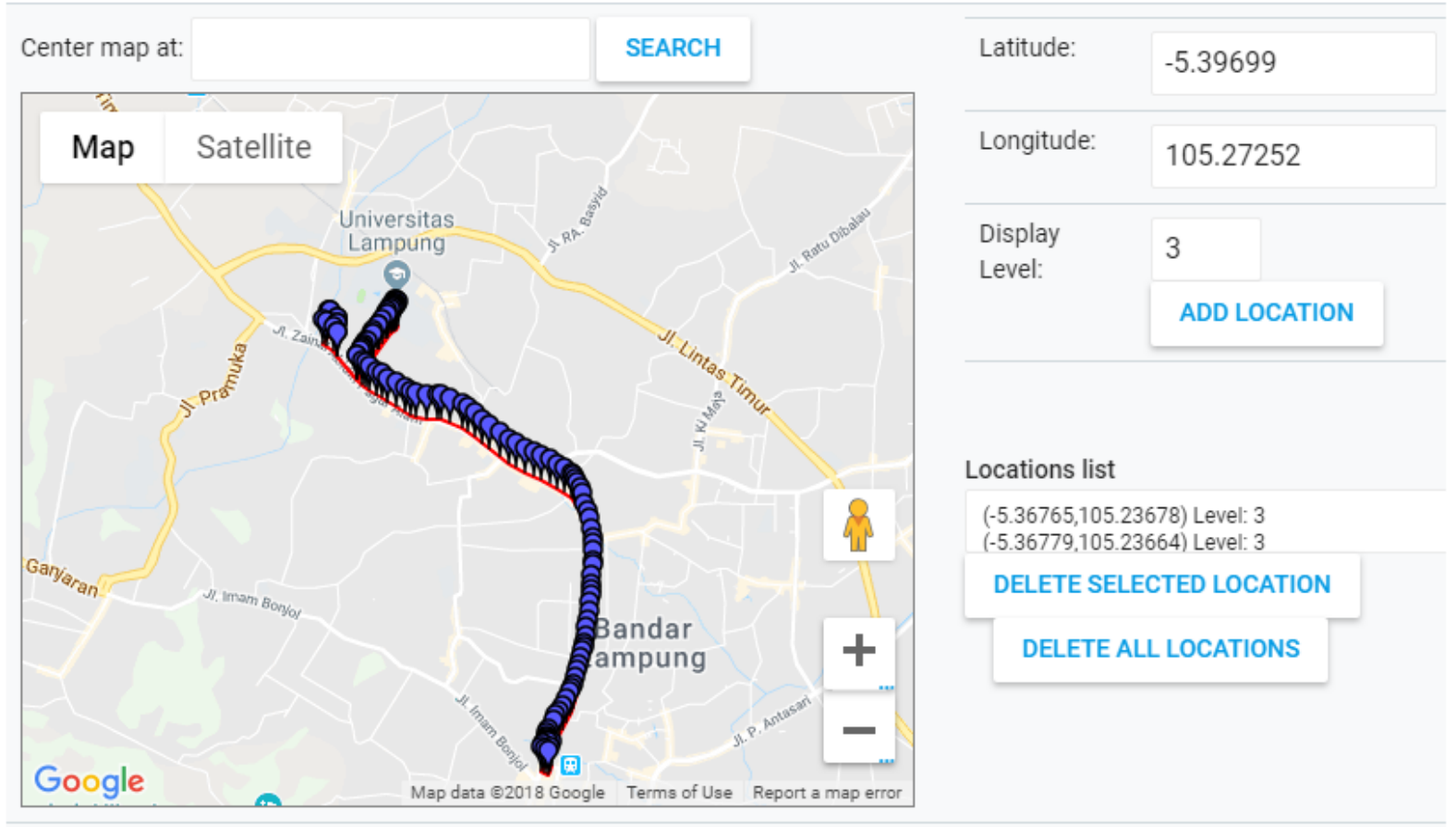

Gambar 1. graph angkutan kota rajabasa-tanjung karang

\section{Pembahasan}

Aplikasi Rute Angkutan Kota Bandar Lampung adalah aplikasi untuk mempermudah masyarakat yang belum mengenal kota Bandar Lampung, untuk mengetahui rute angkutan kota Bandar Lampung. Aplikasi ini dibuat dengan menggunakan bahasa pemrograman java for android. 


\subsection{Implementasi Sistem}

Aplikasi informasi rute angkutan kota Bandar Lampung berbasis Android. Aplikasi ini berguna untuk memudahkan masyarakat dalam mengetahui rute angkutan kota yang terdapat di Bandar Lampung.

Fitur-fitur yang terdapat di aplikasi ini yaitu, saran rute, info angkot, bantuan, dan tentang. Saran rute dapat mencari lokasi yang akan dituju mampu memberikan saran angkutan kota yang digunakan, info angkot berguna untuk melihat informasi-informasi angkutan kota yang ada di kota Bandar Lampung berserta tarif angkutan kota, bantuan berfungsi untuk membantu cara penggunaan aplikasi, dan contact person bertujuan untuk memberikan saran, dan juga dapat melihat identitas pembuat sistem.

Antarmuka saran rute untuk pengguna melakukan pencarian lokasi yang akan dituju. Pengguna dapat langsung mencari lokasi dengan cara mengisi kolom pencarian sesuai tempat yang akan dituju sistem akan memberikan saran angkutan kota apa saja yang akan digunakan dan total tarif. Contoh, pilih icon saran rute, apabila sudah muncul seperti di gambar (b) pengguna dapat melakukan pencarian, dengan cara mengisi kolom pencarian susuai dengan tempat yang akan dituju tekan enter aplikasi memberikan saran angkutan kota yang digunakan dan total tarif.

Antarmuka info angkot berfungsi memberikan informasi angkutan kota apabila pengguna memilih salah satu daftar angkot, aplikasi ini memberikan informasi rute yang dilewati angkot berserta tarif angkot. Contoh pilih menu info angkot, apabila sudah muncul seperti gambar (c) pengguna dapat melihat informasi angkutan kota bandar lampung.

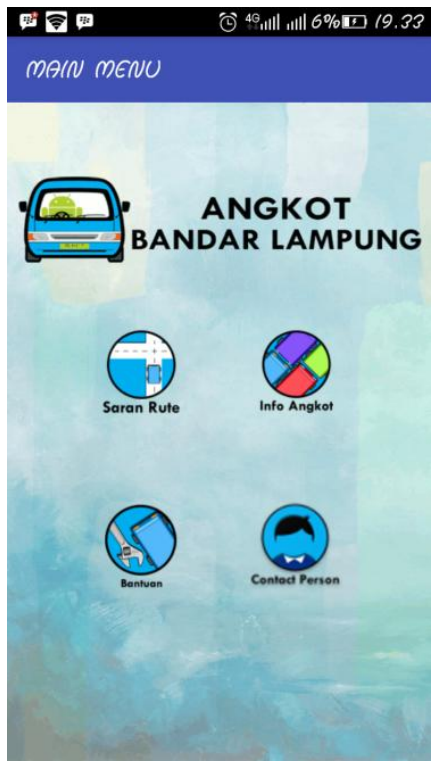

(a)

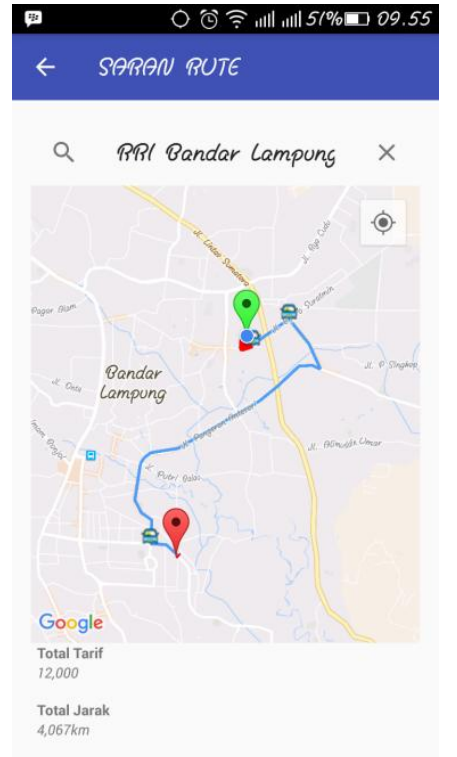

(b)

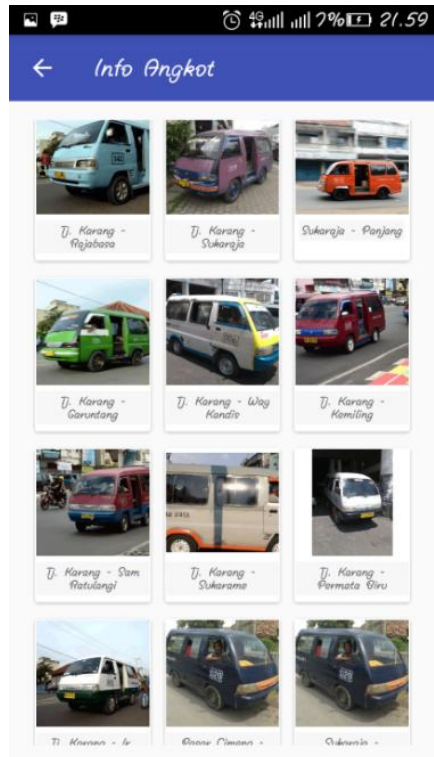

(c)

Gambar 2. Hasil Implementasi (a) Halaman Utama, (b) Saran Rute, (c) Info Angkot

\subsection{Hasil Pengujian}

\subsubsection{Pengujian Fungsional}

Pendekatan kasus uji fungsional dalam penelitian ini adalah pengujian black box dengan metode Equivalence Partitioning (EP)[4]. Pengujian ini dilakukan dengan membagi domain masukan dari program ke dalam kelas-kelas sehingga test case pada perangkat lunak dapat diperoleh. Terdapat Macam pengujian yang terdiri dari 5 (enam) kelas Uji dan dan 15 (delapan belas) 
skenario uji dalam pengujian ini. Dari pengujian tersebut diketahui aplikasi ini dapat berfungsi sesuai dengan realisasi yang diharapkan.

\subsubsection{Pengujian Nonfungsional}

Pengujian non fungsional melibatkan 35 (tiga puluh lima) responden untuk mendapatkan menilaian langsung terhapat sistem yang dihasilkan. Pada pengujian ini responden menggunakan fungsi-fungsi pada aplikasi sistem dan memberikan penilaian terhapat sistem. Dengan demikian pengujian non fungsional telat melibatkan 15 mahasiswa dan 20 masyarakat yang baru berkunjung ke bandar lampung, yang menggunakan smartphone Android. Pengujian ini menggunakan lembar kuisioner yang berisikan pertanyaan-pertanyaan berkaitan dengan sistem yang dihasilkan. Penyusunan bentuk jawaban dari pertanyaan menggunakan skala likert.sebelumnya dilakukan perhitungan dengan skala likert dilakukan perhitungan interval terlebih dahulu. Perhitungan dilakukan dengan persamaan sebagai berikut.

$$
I=\frac{100 \%}{\text { Banyaknya kategori }}=\frac{100 \%}{5}=20 \%
$$

Interval yang diperoleh berdasarkan rumus perhitungan interval tersebut adalah $20 \%$ sehingga kategori penilaian responden adalah sebagai berikut. Tabel kategori penilaian disajikan pada tabel 1

Tabel 1. Ketegori Penilaian

\begin{tabular}{l|l}
\hline \multicolumn{1}{c|}{ Skor } & \multicolumn{1}{c}{ Kategori } \\
\hline $81 \%-100 \%$ & Sangat Baik \\
\hline $61 \%-80 \%$ & Cukup Baik \\
\hline $41 \%-60 \%$ & Baik \\
\hline $21 \%-40 \%$ & Kurang Baik \\
\hline $1 \%-20 \%$ & Tidak Baik \\
\hline
\end{tabular}

\subsubsection{Variabel Fungsi Sistem}

Hasil Penilaian variabel Sistem pada tabel 2.

Tabel 2. Hasil Penilaian Variabel

\begin{tabular}{|c|c|c|c|c|c|c|c|c|}
\hline \multirow[b]{2}{*}{ No } & \multirow[b]{2}{*}{ Kriteria } & \multirow[b]{2}{*}{ Persentase } & \multirow[b]{2}{*}{ Total } & \multicolumn{5}{|c|}{ Kategori } \\
\hline & & & & $\begin{array}{l}5 \\
\text { SB }\end{array}$ & $\begin{array}{l}4 \\
\mathrm{~B}\end{array}$ & $\begin{array}{l}3 \\
\mathrm{CB}\end{array}$ & $\begin{array}{l}2 \\
\mathrm{~KB}\end{array}$ & $\begin{array}{l}1 \\
\mathrm{~TB}\end{array}$ \\
\hline 1 & $\begin{array}{l}\text { Aplikasi dapat memberikan } \\
\text { informasiyang bermanfaat bagi } \\
\text { masyarakat khususnya awam angkot } \\
\text { Bandar Lampung }\end{array}$ & $84,57 \%$ & 148 & 13 & 17 & 5 & 0 & 0 \\
\hline 2 & $\begin{array}{l}\text { Jumlah angkot sesuai dengan angkot } \\
\text { yang terdapat di kota Bandar Lampung }\end{array}$ & $82,28 \%$ & 144 & 9 & 21 & 5 & 0 & 0 \\
\hline 3 & $\begin{array}{l}\text { Aplikasi dapat membantu masyarakat } \\
\text { dalam mengetahui angkot apa saja } \\
\text { yang akan digunakan ketempat tujuan }\end{array}$ & $84,57 \%$ & 148 & 15 & 13 & 7 & 0 & 0 \\
\hline 4 & $\begin{array}{l}\text { Aplikasi berjalan dengan baik dan } \\
\text { sesuai dengan fungsinya }\end{array}$ & $85,71 \%$ & 150 & 13 & 19 & 3 & 0 & 0 \\
\hline 5 & $\begin{array}{l}\text { Aplikasi mudah dipahami dan } \\
\text { digunakan }\end{array}$ & $84 \%$ & 147 & 11 & 20 & 4 & 0 & 0 \\
\hline 6 & $\begin{array}{l}\text { Bagaimana kesuaian warna } \\
\text { background dan teks pada aplikasi }\end{array}$ & $82,85 \%$ & 145 & 11 & 18 & 6 & 0 & 0 \\
\hline 7 & $\begin{array}{l}\text { Bagaimana kualitas gambar pada } \\
\text { aplikasi }\end{array}$ & $81,71 \%$ & 143 & 11 & 16 & 8 & 0 & 0 \\
\hline & Jumlah Persentase & $585,69 \%$ & & & & & & \\
\hline & Rata - rata & & & 83 , & & & & \\
\hline
\end{tabular}


Hasil persentase yang diperoleh untuk setiap kriteria penilaian, maka dapat dilakukan perhitungan untuk mendapatkan nilai rata-rata persentase atau nilai persentase secara keseluruhan sebagai berikut.

$$
\frac{\text { Jumlah Persentase }}{\text { Jumlah Kriteria Penilaian }}=\frac{585,69 \%}{7}=83.67 \%
$$

Hasil rata-rata dari seluruh persentase yang diperoleh adalah $83,67 \%$, sehingga berdasarkan kriteria peniliaian yang dilakukan dalam pengujian non-fungsional dapat disimpulkan bahwa aplikasi yang dibangun termasuk ke dalam kategori "Sangat Baik".

\section{Kesimpulan}

Hasil penelitian yang dilakukan, dapat diambil simpulan sebagai berikut:

1. Aplikasi rute angkutan kota Bandar Lampung, yang digunakan sebagai media untuk memberikan saran rute, apabila pengguna tidak mengetahui angkutan kota yang harus digunakan dan memerikan informasi angkutan kota yang ada di Bandar Lampung serta tarif.

2. Hasil pengujian dapat disimpulkan bahwa semua fungsi pada aplikasi dapat dijalankan dengan baik, seperti pada menu saran rute, menu info angkot, menu bantuan, dan menu tentang.

\section{Referensi}

[1] Hermawan, Pradono. 2012. Analisis Tarif Bus Rapid Trans (BRT) Bandar Lampung Berdasarkan Biaya Operasional Kendaraan, Kemampuan Membayar dan Keinginan Membayar Penumpang. Program Magister Perencanaan Wilayah dan Kota, Sekolah Arsitektur, Perencanaan dan Pengembangan Kebijakan (SAPPK), ITB. Bandung.

[2] Singhal M. 2012. Implementation of Location based Services in Android using GPS and Web Services. ABV-Indian Institute of Information Technology and Management Gwalior, India.

[3] Alves, D. 2012. Retrieving real-time information to users in public transport networks: an application to the Lisbon bus system. Department of Civil Engineering, Portugal.

[4] Pressman, Roger S. 2001.Software Engineering A Practitioner's Approach FifthEdition. McGraw-HillCompanies, Inc, New York. 